\title{
Associated bacterial communities of two deep-water sponges
}

\author{
J. B. Olson ${ }^{1, *}$, P. J. McCarthy ${ }^{2}$ \\ ${ }^{1}$ Department of Biological Sciences, Box 870344, University of Alabama, Tuscaloosa, Alabama 35487, USA \\ ${ }^{2}$ Harbor Branch Oceanographic Institution, 5600 US 1 North, Fort Pierce, Florida 34946, USA
}

\begin{abstract}
A combination of approaches was used to examine the bacterial communities associated with 2 deep-water Scleritoderma spp. sponges. Denaturing gradient gel electrophoresis analysis of partial 16S rRNA genes extracted from sponge tissue was used to determine the structure of the sponge-associated bacterial community. Cultivation studies using a variety of marine-based media and medium additions were performed to characterize the cultivable aerobic heterotrophic bacterial community. DNA was extracted from recovered isolates, mixed, and PCR-denaturing gradient gel electrophoresis was performed to demonstrate the differences between the recoverable microorganisms and the entire bacterial community. Results indicated that, as expected, only a small fraction of the bacterial community could be cultivated and that the isolates appeared to be non-representative of sponge-associated communities for each specimen. Sequences recovered from the denaturing gel demonstrated the greatest similarity based on GenBank comparisons to uncultivated microbial associates of the lithistid sponge Theonella swinhoei and the verongid sponge Aplysina aerophoba, suggesting that the bacterial communities are similar between different host sponges from phylogenetically disparate orders.
\end{abstract}

KEY WORDS: Bacterial community - Sponge-associated bacteria · Denaturing gradient gel electrophoresis · DGGE · Cultivation

- Resale or republication not permitted without written consent of the publisher

\section{INTRODUCTION}

Sponge-microbial associations have long been documented and probably date back to Precambrian times about 500 million years ago (Wilkinson 1984); however, relatively little is known about the nature of the interactions, although recent molecular studies appear to be making progress in this area (e.g. Muller et al. 2004, Regoli et al. 2004). The amount of bacteria residing in sponge species varies dramatically but can constitute up to $60 \%$ of the biomass (Wilkinson $1978 a, b, c)$, suggesting that bacteria may play a crucial role in determining the nutrition, health, and chemical defenses of the host sponge. Because water column microorganisms provide a food source for the filter feeding sponge, differentiating between truly associated species and food species is difficult. This determination is important for gaining a better understanding of the nature and function of the association and also to begin to identify true symbioses.
A community of morphologically diverse bacteria has been found to be associated with various marine sponges through the use of techniques including cultivation (Santavy et al. 1990, Olson et al. 2000, Hentschel et al. 2001, Webster \& Hill 2001) and electron microscopic examination (Friedrich et al. 1999, Webster et al. 2001). Results obtained by various researchers demonstrated that the bacterial communities recovered from sponges were distinct from those recovered from ambient seawater (Wilkinson 1978b, Santavy \& Colwell 1990, Burja \& Hill 2001, Hentschel et al. 2002). These diverse microbial communities may play a role in many biological functions, whether beneficial to the host organism or not. Our laboratory has performed cultivation studies using numerous marine media with various media additions aimed at increasing the aerotolerance of the microbes. These studies demonstrated that microbial recoverability could be increased by employing the media additions, but that responses were dependent upon the media 
composition and media supplement used (Olson et al. 2000). Even with this increase in recoverability, it was still not possible to conclusively differentiate among transient organisms (unphagocytized food or watercolumn bacteria) and those specifically associated with the host sponge.

Recently, investigators have begun to apply molecular methods to characterize sponge-associated microbial communities. Hentschel et al. (2002), working with approximately 6 individuals from 2 shallow-water species and sequences obtained from 2 other species by other researchers (Altoff et al. 1998, Webster et al. 2001), found that sponges from different oceans supported similar, yet phylogenetically diverse, microbial communities. In contrast, Webster et al. (2004) and Taylor et al. (2004), working with marine sponges from the Antarctic and Australia, respectively, found that bacterial sequences from those organisms shared little phylogenetic similarity to other sponge-derived bacterial sequences. The authors acknowledged that the lack of sequence similarity may have been due to the extreme environment of the Antarctic or to differences in sample selection and/or methodologies.

The aim of the present study was to examine the composition of the bacterial communities of 2 deepwater Scleritoderma spp. sponges by cultivation and by denaturing gradient gel electrophoresis (DGGE) analysis of partial 16S rRNA genes from bacterial DNA isolated from sponge tissue. In addition, we isolated DNA from the bacteria cultured from sponge tissue and analyzed this community by DGGE as well. The combination of traditional cultivation and molecular approaches was used to emphasize similarities and differences in the results obtained regarding the composition of the microbial community and to help differentiate between transient and associated populations.

\section{MATERIALS AND METHODS}

Experimental design. Deep-water sponges were collected during exploratory submersible dives in which the goal was to sample the highest diversity of marine life; this precluded collecting replicate sponge samples. One lithistid sponge was collected at depth from each of 2 geographically distinct locations using a manned, deep-diving submersible, and sponge tissue was carefully excised to reduce the presence of transient bacteria. The sponge tissue was homogenized and subsampled. DNA was extracted from 1 subsample and the community structure of associated bacterial populations determined using DGGE. Bacteria were cultured from the other subsample using a variety of media and supplements. DNA was extracted from the isolates, combined, and this mixture was used as a template for PCR. The 2 contrasting communities, culturable bacteria and bacteria detected by PCR amplification of DNA recovered from sponge tissue, were then compared using DGGE.

Sponge collection. Two lithistid source sponges were collected from deep-water sites in the Netherlands Antilles using Harbor Branch Oceanographic Institution's Johnson-Sea-Link I submersible during May 2000. The first sponge (Scleritoderma cyanea, sample \# 12-V-00-3-004) was retrieved from a rock overhang at $242 \mathrm{~m}$ depth off the coast of Curaçao. Four days later, the second sponge (Scleritoderma sp., sample \# 16-V-00-1-001) was collected off the coast of Bonaire from a rock substrate at $255 \mathrm{~m}$ depth. In situ measurements taken during the dives indicated that water conditions (e.g. temperature $=12$ to $15^{\circ} \mathrm{C}, \mathrm{pH}$, salinity) were similar for the 2 sponges. The 2 sponges were collected by suction, placed into Plexiglas buckets mounted on the submersible work platform and aseptically removed from the buckets on return to the surface. Morphology was recorded, and small portions were subsampled for analysis and identification. The sponges were identified through examination of spicule preparations and morphological features. Small sections of the sponges $(\sim 5 \mathrm{~g}$ wet weight including both pinacoderm and mesohyl regions) were gently rinsed in sterile natural seawater, cut into smaller pieces, and homogenized at low speed with an ethanol sterilized VirTis high-speed homogenizer. Resulting supernatants were serially diluted in sterile natural seawater. The remaining undiluted sponge suspension was stored at $-80^{\circ} \mathrm{C}$ with an equal volume of TE buffer (10 mM Tris-HCl, 1 mM EDTA, pH 8.0) for molecular analyses.

Isolation media and growth conditions. Five media were used for cultivation of sponge-associated marine microorganisms. OLIGO is a recipe from Santavy \& Colwell (1990), while C-mix, maltose-supplemented seawater $\left(\mathrm{MsH}_{2} \mathrm{O}\right)$ and 60:40 were used in a previous recoverability study (Olson et al. 2000). The final medium, MUCIN, was prepared using $1.0 \mathrm{~g}$ mucin, $1.0 \mathrm{ml}$ trace metal solution $\left(2.86 \mathrm{~g} \mathrm{H}_{3} \mathrm{BO}_{3}, 1.81 \mathrm{~g} \mathrm{MnCl}_{2}\right.$ - $4 \mathrm{H}_{2} \mathrm{O}, 1.36 \mathrm{~g} \mathrm{FeEDTA}, 0.08 \mathrm{~g} \mathrm{CuSO}_{4} \cdot 5 \mathrm{H}_{2} \mathrm{O}, 0.049 \mathrm{~g}$ $\mathrm{Co}\left(\mathrm{NO}_{3}\right)_{2} \cdot 6 \mathrm{H}_{2} \mathrm{O}, 0.39 \mathrm{~g} \mathrm{NaMoO} \cdot 2 \mathrm{H}_{2} \mathrm{O}, 0.22 \mathrm{~g} \mathrm{ZnSO}$ - $7 \mathrm{H}_{2} \mathrm{O}, 1 \mathrm{l}$ distilled $\mathrm{H}_{2} \mathrm{O}$ ), $1.0 \mathrm{ml} \mathrm{PO}_{4}{ }^{-}$solution $(5.0 \mathrm{~g}$ $\mathrm{NaH}_{2} \mathrm{PO}_{4} \cdot \mathrm{H}_{2} \mathrm{O}, 1 \mathrm{l}$ distilled $\mathrm{H}_{2} \mathrm{O}$ ), 11 filtered seawater, and $10 \mathrm{~g}$ agar. All media were prepared immediately prior to the expedition and stored in sealed sleeves in the dark to minimize photo-oxidation and free radical formation. A control (unsupplemented) and plates supplemented with catalase $\left(100 \mathrm{U} \mathrm{ml}^{-1}\right.$ filter sterilized and added to molten media; Padgett et al. 1982, Calabrese \& Bissonnette 1990), sodium pyruvate (1\% wt/vol added to media prior to autoclaving; Martin et al. 1976, Calabrese \& Bissonnette 1990), and norepine- 
phrine $(50 \mu \mathrm{M}$ final concentration with $1.8 \mu \mathrm{M} \mathrm{FeCl}$ solution, filter sterilized and added to molten media) were used for each medium inoculated. Triplicate plates for each supplement for the 5 media were inoculated with $50 \mu \mathrm{l}$ of sponge supernatant dilutions for 2 dilutions per experiment using the spread plate technique. All plates were allowed to dry overnight in the dark prior to placing into sleeves for storage. Inoculated plates were stored inverted in sealed sleeves in the dark at room temperature (approx. 20 to $25^{\circ} \mathrm{C}$ ) for a minimum of 28 d. Following incubation, individual colonies were selected for isolation based on colony morphology. Colonies were transferred to fresh plates of the isolation media and incubated at room temperature in the dark. Individual colonies were streaked onto fresh plates until pure cultures were obtained.

DNA extraction and PCR amplification. Bacterial isolates were grown to stationary phase in liquid media (marine broth; $5 \mathrm{~g}$ peptone, $1 \mathrm{~g}$ yeast extract, $1 \mathrm{ml}$ trace metal solution, 11 artificial seawater), and cells from $1 \mathrm{ml}$ of culture medium recovered by centrifugation for 2 min at $16000 \times g$. The cell pellet was resuspended in $100 \mu \mathrm{l}$ of a sterile $5 \%$ Chelex 100 suspension (100 to 200 mesh sodium form resin [Bio-Rad Laboratories] in distilled water). DNA was extracted by incubating at $70^{\circ} \mathrm{C}$ for $1 \mathrm{~h}$ with vigorous vortexing every $15 \mathrm{~min}$ followed by 2 to 4 freeze-thaw cycles. Successful DNA extraction was verified for randomly selected Gramnegative and Gram-positive isolates. For each source sponge, a $2 \mu$ subsample of extraction mixture from each isolate was combined and this pooled DNA used for PCR amplifications.

DNA from the sponge suspensions was obtained by centrifuging $3.0 \mathrm{ml}$ of the TE stored sample for $5 \mathrm{~min}$ at $16000 \times g$, removing the majority of the supernatant ( 2.75 to $2.85 \mathrm{ml})$, and using the remaining cell pellet for extraction with the Qiagen DNeasy Plant Mini Kit (Qiagen). A $3 \mathrm{~h} 70^{\circ} \mathrm{C}$ incubation step with periodic vigorous vortexing replaced the manual's suggested $10 \min 65^{\circ} \mathrm{C}$ incubation procedure. All other steps were performed as recommended by the manufacturer. The resulting eluates were further cleaned through the use of Qiagen DNeasy tissue kits in order to obtain samples sufficiently clean for PCR amplifications.

Universal bacterial primers 8F and GC536R (with a 40 bp GC clamp; Sheffield et al. 1989) (8F: 5'-AGAGTTTGATCCTGGCTCAG-3', and GC536R: 5'-CGCCCGGGGCGCGCCCCGGGCGGGGCGGG GCACGGGGGGCGGCCGCGGCTGCTGGCACGT A-3'; Lane et al. 1985) were used to amplify a portion of the 16S rRNA gene from both bacterial DNA isolated from sponge tissue and bacterial DNA from organisms isolated from sponge tissue. Amplification conditions were $94^{\circ} \mathrm{C}$ for $1 \mathrm{~min}, 55^{\circ} \mathrm{C}$ for $1 \mathrm{~min}$, and $72^{\circ} \mathrm{C}$ for $1.5 \mathrm{~min}$, with a $7 \mathrm{~min} 72^{\circ} \mathrm{C}$ final extension following the 30th cycle. Amplification products were electrophoresed on a $1 \%$ agarose gel, stained with ethidium bromide, and visualized under UV transillumination. PCR products from 3 separate amplification reactions were pooled and ethanol precipitated to reduce sample bias and concentrate the DNA. The resulting pellets were resuspended in $40 \mu \mathrm{l}$ of TE buffer.

DGGE. DGGE was performed using a DCode Universal Mutation Detection System (Bio-Rad). The $16 \times$ $16 \mathrm{~cm} 6.5 \%$ polyacrylamide gradient gel was cast until it was approximately $1 \mathrm{~cm}$ below the end of the comb teeth and allowed to polymerize. In order to eliminate pooling of unpolymerized denaturant in the wells, a $0 \%$ denaturant polyacrylamide gel was cast on top of the gradient gel into which the comb was inserted. Gradient gels were prepared with a denaturant gradient of formamide and urea from 30 to $70 \%$ (using 0 and $100 \%$ denaturant stock solutions) and polymerized by addition of ammonium persulfate and TEMED according to the DCode system manual. PCRamplified DNA $(30 \mu \mathrm{l})$ was loaded onto the gel and run at a constant voltage of $100 \mathrm{~V}$ at $60^{\circ} \mathrm{C}$ for $16 \mathrm{~h}$ in a $1.25 \times$ TAE buffer. Gels were removed from the glass plates and stained with ethidium bromide for $30 \mathrm{~min}$ followed by a $1 \mathrm{~h}$ destain in $0.5 \times$ TAE buffer. Gels were documented using UV transillumination and Polaroid photography. Polaroid photographs were scanned and inverse images acquired using Adobe Photoshop software.

Individual bands were excised from the acrylamide gel using sterile technique and placed into microcentrifuge tubes with $20 \mu \mathrm{l}$ sterile water. The tubes were vortexed vigorously and incubated at $4{ }^{\circ} \mathrm{C}$ for $24 \mathrm{~h}$. PCR amplifications were performed using $1 \mu \mathrm{l}$ of the DNA eluted from the bands and non-GC-clamped 16S rRNA primers 8F and 536R (5'-GWATTACCGCGGCKGCTG-3') for 30 cycles as described previously. Amplification products were stained and visualized under UV transillumination. The correctly sized products were cut out of the gel, purified with a Geneclean II kit (Bio 101), ligated into vector pCR 2.1 (TA Cloning Kit; Invitrogen), and used to transform Escherichia coli according to the manufacturer's instructions. Plasmids with inserts of the correct size were sequenced at the University of Florida DNA Core Sequencing Facility using the fluorescent dideoxy terminator method on an Applied Biosystems 373A or 377 automated DNA sequencer.

The sequences obtained during this study are available at GenBank under accession numbers AY046061 to AY046068. Aligned partial 16S rRNA sequences were analyzed using parsimony with PAUP* $4.0 \mathrm{~b} 10$ (Swofford 2002). A bootstrap analysis with 1000 iterations was conducted (Felsenstein 1985). NIH Image software (available http://rsb.info.nih.gov/nih-image/) 
was used to determine presence, spatial relationships, and fluorescent intensities of the DGGE banding patterns. Peaks were counted as distinct bands if they were approximately 2 times larger than the background level and had distinct upslopes and downslopes with a discernable peak. These criteria were the same for co-eluting shoulder peaks.

\section{RESULTS}

\section{Isolation studies}

In total, 120 microbial isolates were obtained from the Scleritoderma spp. sponges collected (by chance, 60 isolates from 12-V-00-3-004 and 60 isolates from 16V-00-1-001). Similar numbers of isolates were recovered from the 2 sponges on each medium employed. Two of the media used yielded greater numbers of isolates than the remaining 3 but did not share similar carbon availability or nutritional content, suggesting that sponge-associated microbial communities exhibit substantial metabolic diversity. Growth from OLIGO and C-mix media combined provided 58.2 and $59.9 \%$ of the isolates recovered from each sponge sample, while 60:40 and maltose-supplemented seawater media jointly accounted for only 23.3 and $18.3 \%$ of the isolates (Table 1). Media supplemented with mucin, used to mimic the mucilage and polysaccharide material commonly found associated with marine sponges, provided the median range of recoverability, with 18.3 and $21.6 \%$ of the isolates.

Table 1. Number of isolates recovered from each medium treatment. Note that statistical analyses were not conducted as 30 to 300 colonies were not recovered per plate. $\mathrm{sH}_{2} \mathrm{O}$ : seawater

\begin{tabular}{|c|c|c|c|c|c|}
\hline \multirow[t]{2}{*}{ Medium } & \multicolumn{4}{|c|}{ Isolates per treatment } & \multirow{2}{*}{$\begin{array}{c}\text { Total } \\
\text { isolates }\end{array}$} \\
\hline & $\begin{array}{l}\text { Un- } \\
\text { amended }\end{array}$ & Catalase & $\begin{array}{l}\text { Sodium } \\
\text { pyruvate }\end{array}$ & $\begin{array}{l}\text { Norepine- } \\
\text { phrine }\end{array}$ & \\
\hline \multicolumn{6}{|l|}{$12-\mathrm{V}-00-3-004$} \\
\hline OLIGO & 3 & 5 & 6 & 2 & 16 \\
\hline $60: 40$ & 1 & 1 & 1 & 3 & 6 \\
\hline $\begin{array}{l}\text { Maltose- } \\
\text { supplemented } \mathrm{sH}_{2} \mathrm{O}\end{array}$ & 3 & 1 & 3 & 1 & 8 \\
\hline C-Mix & 1 & 4 & 8 & 6 & 19 \\
\hline Mucin & 1 & 5 & 4 & 1 & 11 \\
\hline Total & 9 & 16 & 22 & 13 & 60 \\
\hline \multicolumn{6}{|l|}{$16-V-00-1-001$} \\
\hline OLIGO & 2 & 6 & 4 & 4 & 16 \\
\hline $60: 40$ & 2 & 4 & 2 & 0 & 8 \\
\hline $\begin{array}{l}\text { Maltose- } \\
\text { supplemented } \mathrm{sH}_{2} \mathrm{O}\end{array}$ & o & 0 & 0 & 3 & 3 \\
\hline C-Mix & 3 & 5 & 8 & 4 & 20 \\
\hline Mucin & 3 & 7 & 1 & 2 & 13 \\
\hline Total & 10 & 22 & 15 & 13 & 60 \\
\hline
\end{tabular}

For the media treatments, media supplemented with either catalase or sodium pyruvate provided the maximal number of isolates, accounting jointly for over $60 \%$ of the recovered microorganisms for each sponge sample (Table 1). Unamended media and norepinephrine-supplemented media yielded lower numbers of colonies. Similar numbers of isolates were obtained for the 2 geographically distinct sponge samples with each of the media amendments.

The majority of the recovered organisms stained gram-negative, which was expected from Gram stains performed on the whole sponge supernatants (>80\% gram-negative; J. B. Olson pers. obs.). A large majority of the isolates displayed a rod-shaped cellular morphology, with highly variable lengths and widths. A much smaller number were found to be cocci, often occurring in tetrads and clumps. About one-third of the isolates demonstrated substantial colony pigmentation, mostly occurring in the beige, yellow, and orange hues. The pigmented coccoid isolates were far more likely to stain gram-positive than other isolates.

\section{DGGE results}

The DGGE banding patterns of the bacterial DNA isolated from the 2 species of sponge showed a number of co-occurring bands (Fig. 1, Lanes 1 and 4). NIH Image scans revealed that Lane 1 contained 26 distinct bands and Lane 4 contained 19 bands and that these lanes shared 12 bands in common, a 46 and $63 \%$ commonality, respectively (Fig. 2). The DGGE banding patterns of the bacterial DNA from organisms cultured from the 2 sponge species also showed co-occurring bands (Fig. 1, Lanes 2 and 5). NIH Image scans revealed that Lane 2 contained 11 distinct bands and Lane 5 contained 10 bands and that $45 \%$ of the bands in these 2 lanes were common to both (Fig. 2).

The DGGE banding patterns of the bacterial DNA isolated from sponge tissue and bacterial DNA from organisms cultured from sponge tissue were different (Fig. 1, Lanes 1 and 4 vs. 2 and 5). For each sponge specimen, there are far more visible bands, ranging across a larger denaturant gradient, in the bacterial DNA isolated from sponge tissue than for the bacterial DNA from organisms cultured from sponge tissue. Lane 1 shared only 1 band with Lanes 2 and $5(4 \%)$, the bacterial DNA from organisms cultured from sponge tissue 


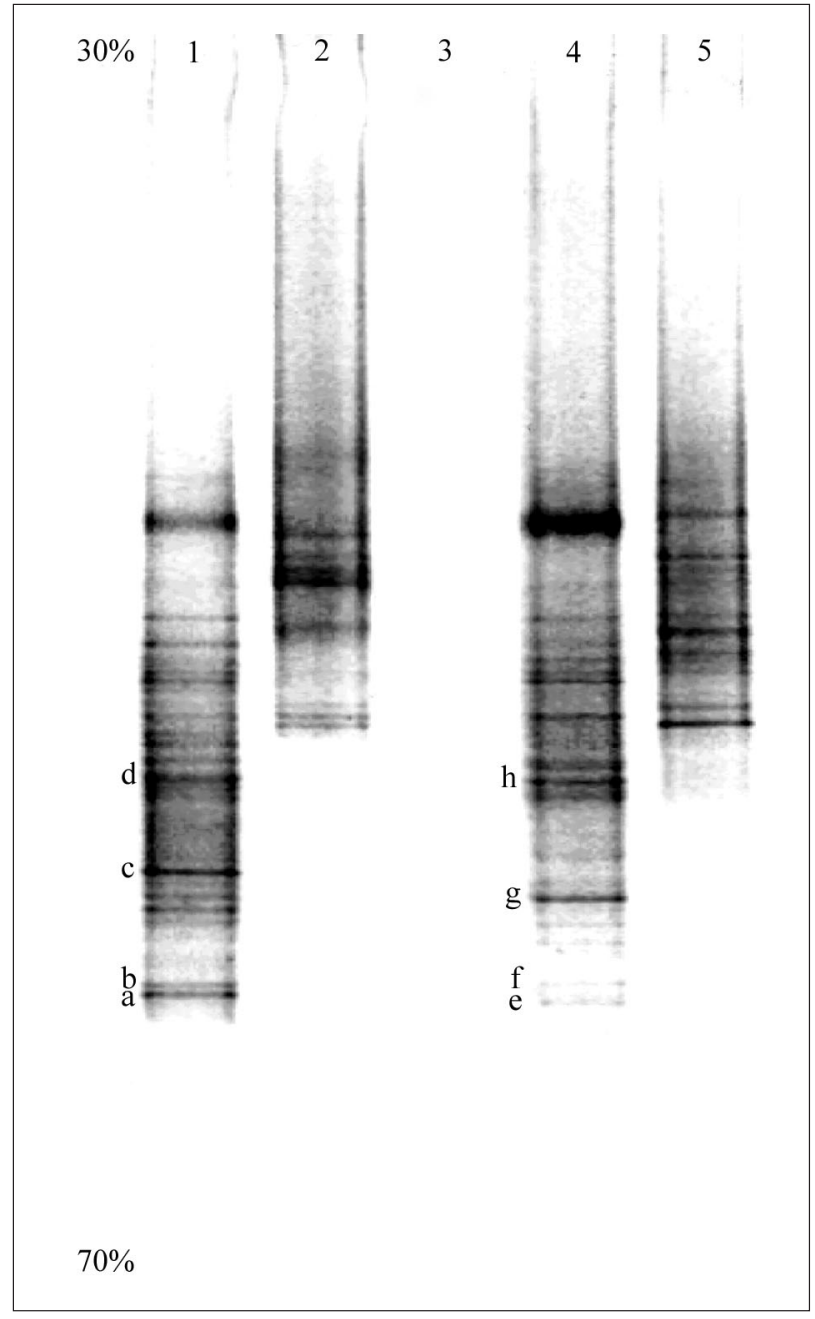

Fig. 1. DGGE patterns obtained for the 2 sponge samples and the isolates obtained from each sponge. The products from 3 PCR amplifications were pooled to provide sufficient DNA for good resolution of bands. a-h: bands that were excised and sequenced (see Fig. 3). Lane 1: bacterial DNA isolated from sponge 12-V-00-3-004 tissue; Lane 2: bacterial DNA from organisms cultured from sponge 12-V-00-3-004 tissue; Lane 3: empty; Lane 4: bacterial DNA isolated from sponge 16-V-00-1-001 tissue; Lane 5: bacterial DNA from organisms cultured from sponge 16-V-00-1-001 tissue. The gel contained a denaturant gradient from $30 \%$ (top) to $70 \%$ (bottom)

samples. Of the 19 bands in Lane 4, only 1 (5\%) was common to Lanes 2 and 5. The bands that migrated farther on the denaturant gel appear only in the bacterial DNA isolated from sponge tissue lanes, suggesting that similar bacteria were not obtained in culture. Furthermore, very few bands observed in the culturable bacterial community lanes were observed in the bacterial DNA isolated from sponge tissue lanes, suggesting that the isolated organisms may not have been numerically dominant bacteria in the sponges. Only 10 to 11 distinct bands were seen in the bacterial DNA from organisms cultured from sponge tissue lanes (2 and 5) after PCR amplification, although DNA extracted from 55 to 59 bacterial isolates (fungal isolates subtracted from totals) was pooled to provide the template for PCR amplification.

Eight DGGE bands from bacterial DNA isolated from sponge tissue were successfully sequenced and their phylogenetic relationships to other bacteria determined based on sequence information available in GenBank (Fig. 3). The Chimera Check program on the Ribosomal Database Project II website (http:// rdp.cme.msu.edu/html/analyses.html) was used to verify that the recovered sequences were most likely not combinations of multiple sequences. Using GenBank Blastn searches for each sequence, the closest matches were recovered from uncultivated environmental clones, with 5 of the 8 sequenced bands $(\mathrm{a}-\mathrm{c}, \mathrm{e}, \mathrm{g})$ being most similar to other sponge-derived sequences (data not shown).

Percent $\mathrm{G}+\mathrm{C}$ content was determined for each of the sequences: $\mathrm{a}=63.0, \mathrm{~b}=62.5, \mathrm{c}=62.4, \mathrm{~d}=58.7, \mathrm{e}=63.3$, $\mathrm{f}=63.1, \mathrm{~g}=59.4, \mathrm{~h}=57.8$. Band pairs a and $\mathrm{e}, \mathrm{b}$ and $\mathrm{f}$, and $d$ and $h$ in Fig. 1, which migrated similarly but had different sequence information, displayed similar $\mathrm{G}+\mathrm{C}$ content for the amplified fragments. Conversely, there was a discrepancy in the $\mathrm{G}+\mathrm{C}$ content and migration patterns for bands c and $\mathrm{g}$. These results demonstrate, as has been shown previously (e.g. Myers et al. 1987, Muyzer \& Smalla 1998), that the migration of DNA through denaturing gels is affected by melting domain structure as well as by nucleotide composition and sequence length.

\section{DISCUSSION}

This study compares the DGGE banding patterns of a reconstructed culturable microbial community and the bacterial community detected by PCR amplification of DNA isolated from sponge tissue. Previous studies have compared DNA sequences from cultured organisms to sequences obtained from the environmental sample (e.g. Santegoeds et al. 1996, Suzuki et al. 1997, Eilers et al. 2000, Rohwer et al. 2001), but this is the first time to the authors' knowledge that both communities have been compared using DGGE.

DGGE analysis of the bacterial DNA isolated from sponge tissue of the 2 deep-water species indicated that they shared some bacterial populations. A recent study by Hentschel et al. (2002) demonstrated that 6 demosponges from different oceans also shared a relatively uniform microbial community. This led the authors to hypothesize that the sponge environment must impose strong selective pressures on the compo- 


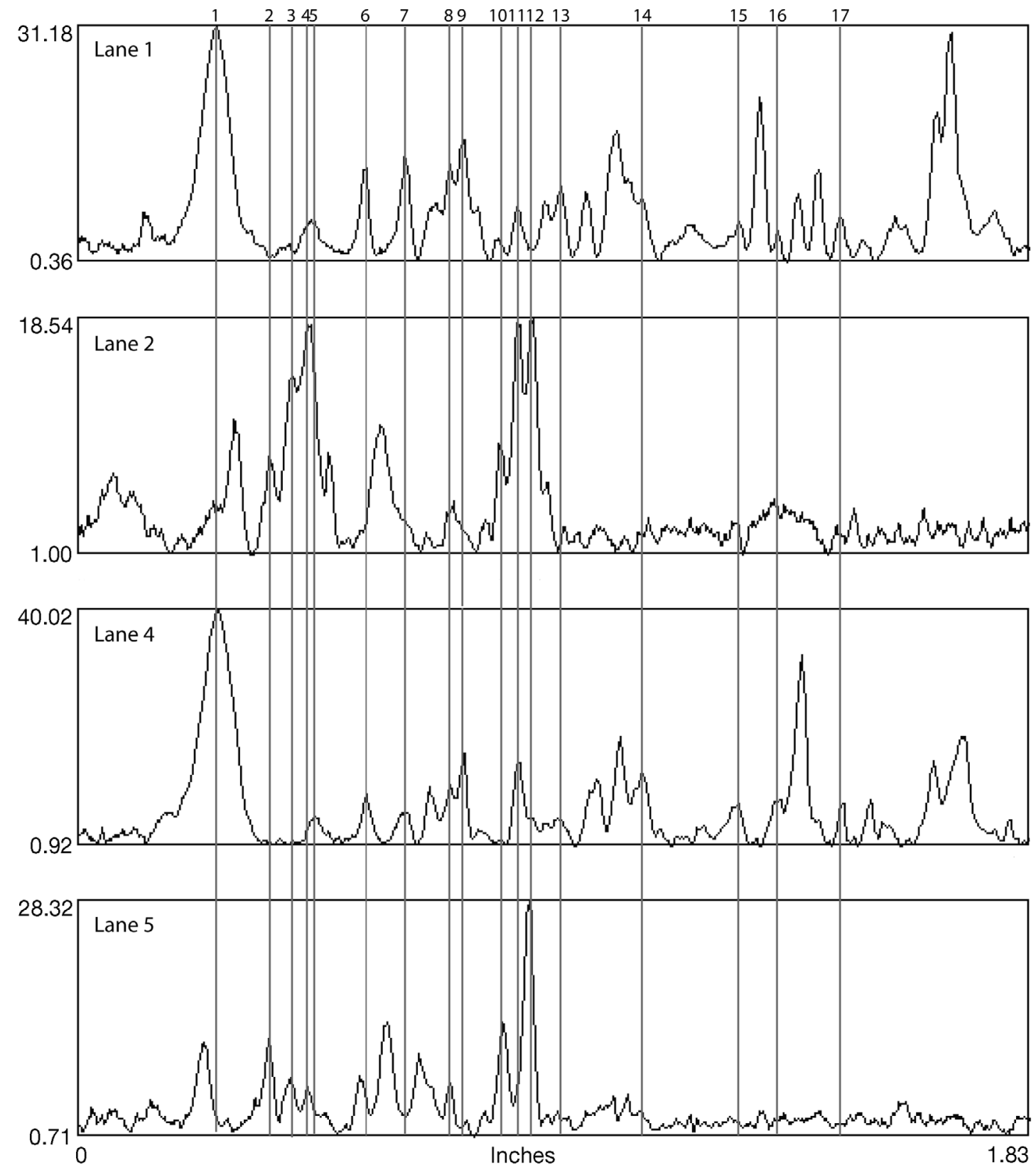

Fig. 2. NIH Image analysis of the banding patterns for each lane. The $y$-axis shows the fluorescent relative intensities of the individual bands once the background was removed. Numbered vertical gray lines indicate peaks that appear in 2 or more lanes

sition of the microbial communities to account for the differences to bacteria in the surrounding seawater. None of the sequences obtained in this study were closely related to planktonic bacteria (which have a large representation in GenBank; Hagström et al. 2002), but instead largely grouped with other spongederived sequences, falling primarily within the Actinobacteria-1 and Acidobacteria-1 clusters designated by Hentschel et al. (2002). Results from their study and others (e.g. Friedrich et al. 1999, Webster et al. 2001) were obtained from shallow-water sponges which commonly support photosynthetic microorganisms associated with the outer sponge layers, suggesting some expected overlap between individuals. The sequence analysis conducted in this study extends the observed similarities in associated bacterial communities to deep-water sponges where no phototrophic organisms were noted. These results conflict with a recent study by Taylor et al. (2004), who found little variation within individual sponge species but substantial variation among 3 shallow-water Australian sponge species, suggesting that additional studies 


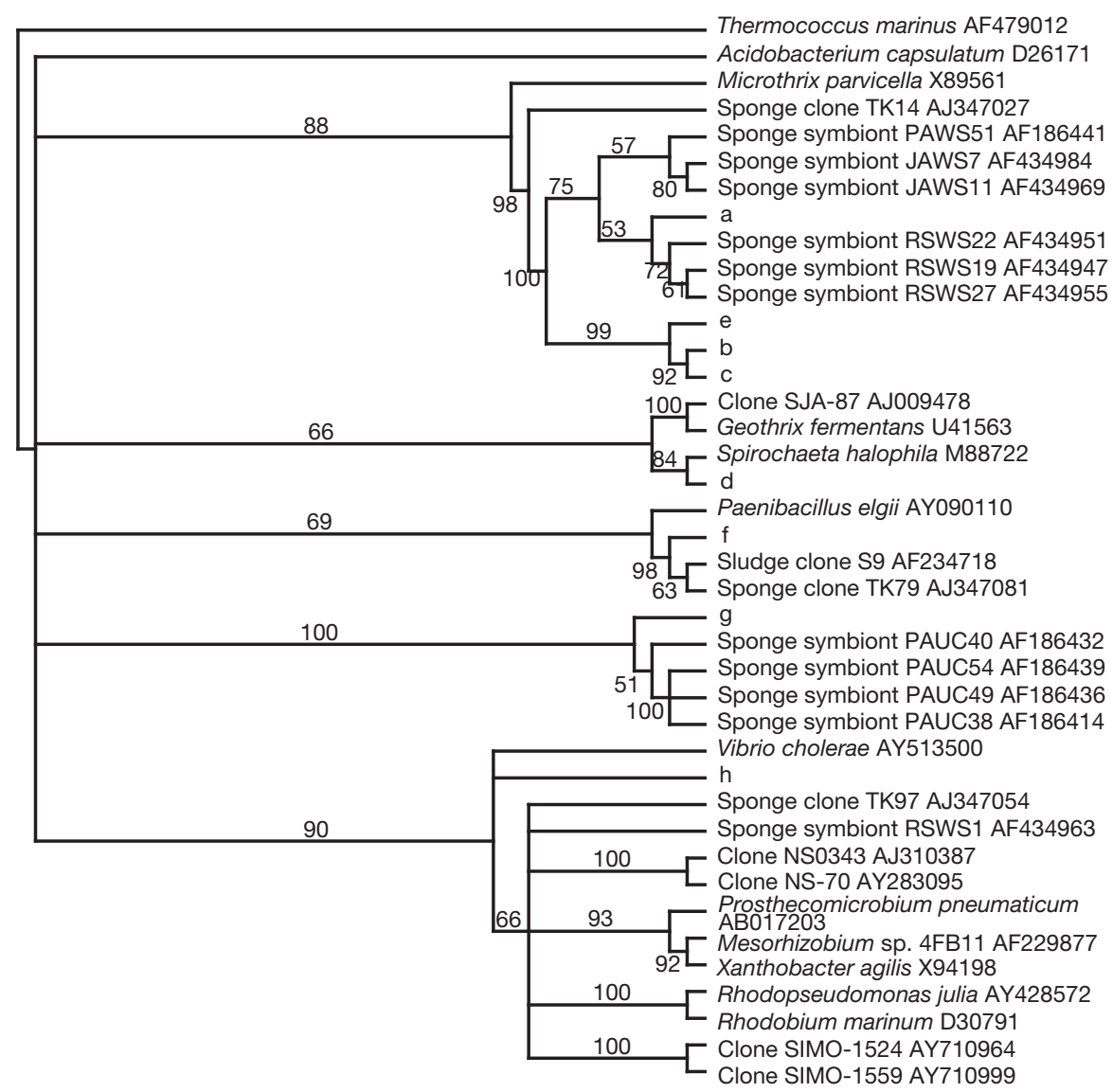

Fig. 3. Majority rule consensus tree prepared in PAUP* using partial 16S rRNA sequences. Bootstrap values greater than $50 \%$ are shown

whether or not they are dominant members of the bacterial communities. Webster \& Hill (2001) estimated that approximately $0.1 \%$ of the total bacterial community was amenable to culture under the conditions used in their study. Based on the banding patterns observed for the DGGE analysis, the additional media and supplements used in this study provided a $\sim 5 \%$ overlap between bacterial DNA from cultured organisms and from sponge tissue. This suggests that at least $5 \%$ of the bacterial community represented by DGGE bands was amenable to cultivation. This estimate falls within the 3.4 to $11 \%$ bacterial recoverability found by Santavy et al. (1990), who also employed a variety of growth media, with a Ceratoporella nicholsoni sponge.

DGGE demonstrated the differences between bacterial community structure as determined by molecular genetic analysis of environmental material and cultivation. Both approaches are recognized to have limitations, suggesting possible sources of the observed disparities. Different banding patterns were shown for the bacterial DNA from organisms cultured from sponge tissue versus the

need to be performed. The sponge species used in Taylor et al.'s (2004) study belonged to 3 different families while the 2 sponges used in this study were from the same genus, which may explain some of the differences noted between the studies.

Although constrained by the small sample size, DGGE analysis of DNA from bacteria isolated from sponge tissue for the 2 samples showed that the culturable communities had some commonalities. Previous studies with both shallow and deep-water sponges revealed that closely related $\alpha$-proteobacteria were consistently cultured from a variety of species (Hentschel et al. 2001, Webster \& Hill 2001, Webster et al. 2001, Olson et al. 2002). Webster \& Hill (2001), using fluorescence in situ hybridization (FISH) techniques, were able to localize the dominant $\alpha$-proteobacteria in Rhopaloeides odorabile to choanocyte chambers of the mesohyl region, while Friedrich et al. (1999), also using FISH analysis, failed to localize their closely related strain to sponge tissues. These contradictory results suggest that similar $\alpha$-proteobacteria are commonly isolated in studies of sponge-microbial interactions, bacterial DNA isolated from sponge tissue, with more bands visualized across a wider denaturant range in the bacterial DNA isolated from sponge tissue lanes. This would suggest that either the PCR amplifications were different for the 2 communities or that the isolates obtained were not numerically prevalent in the sponge microbial community. It has been shown that differences in sample matrix affect DNA extraction efficiencies (e.g. Krsek \& Wellington 1999, Roose-Amsaleg et al. 2001, de Lipthay et al. 2004). PCR amplifications have also been shown to be affected by biases in primer annealing efficiencies (Suzuki \& Giovannoni 1996, Head et al. 1998). This may account for the disparity of visible bands between the PCR products for the bacterial isolates cultured from the sponge and the bacterial DNA extracted from the sponge. Several studies have demonstrated the utility of DGGE approaches for detecting minor bacterial populations ( 1 to $5 \%$ of the whole template DNA) within a community (e.g. Muyzer et al. 1997, Katano \& Fukui 2003). The lack of correlation between the banding patterns suggests that the recovered isolates were not numeri- 
cally dominant members of the bacterial community. The isolates obtained most likely contain significant numbers of repeated cultivation of the same or closely related organisms, indicating that a far greater diversity of organisms exists in the sponge samples than that represented by the isolates.

Combined cultivation and molecular genetic approaches suggest that the 2 isolates that appear in both bacterial DNA isolated from sponge tissue and DNA from bacteria cultured from sponge tissue DGGE lanes are good candidates for future studies on the characteristics of sponge-associated bacteria. In order to better understand the nature of the sponge-microbe interaction, physiology studies will be required, which necessitate cultivation of the bacteria. Unique bands on the DGGE gels suggest the presence of unique microorganisms that could be useful in natural product research but that may be currently uncultivable. From these results, it appears that researchers examining marine sponges for novel compounds may recover a vastly different suite of bacterial isolates for testing compared to the diversity that apparently exists in the sponge samples. Four of the sequenced bands showed the greatest similarity to the Actinobacteria-1 cluster of Hentschel et al. (2002). Actinobacteria have traditionally played an important role in natural product research, as many of our antibiotics have originated in this group. This discrepancy in recovery of associated microorganisms may stymie drug discovery efforts when a compound of interest is recovered from an entire sponge specimen but the producing organism(s) is not recoverable.

Sponges do appear to be reservoirs of currently uncultured, elusive marine microorganisms. Although these data do not differentiate between transient and specifically sponge-associated bacteria, trends do appear to be emerging. This combination of approaches will continue to provide more information on the composition and function of microbial communities than either approach individually and will allow researchers to determine if microbial recoveries are increased, a useful tool in drug discovery applications.

Acknowledgements. We would like to thank B. Walls and R. Russo for assistance in isolation studies and the crews of the RV 'Seward Johnson II' and the 'Johnson-Sea-Link I' submersible for their assistance with sample collection and processing. Thanks also to R. Findlay for reviewing this manuscript and S. Pomponi for sponge identifications. Funding for this project was provided by NOAA's National Sea Grant College Program for proposal R/LR-MB-11 (\#T-99-57). Permits were obtained for sample collection and analysis from the governments of the specified countries. This is Harbor Branch Oceanographic Institution Contribution Number 1591.

\section{LITERATURE CITED}

Altoff, K, Schutt C, Steffen R, Batel R, Muller WEG (1998) Evidence for a symbiosis between bacteria of the genus Rhodobacter and the marine sponge Halichondria panacea: harbor also for putatively toxic bacteria? Mar Biol 130:529-536

Burja AM, Hill RT (2001) Microbial symbionts of the Australian Great Barrier Reef sponge, Candidaspongia flabellata. Hydrobiologia 461:41-47

Calabrese JP, Bissonnette GK (1990) Improved detection of acid mine water stressed coliform bacteria on media containing catalase and sodium pyruvate. Can J Microbiol 36: $544-550$

de Lipthay JR, Enzinger C, Johnsen K, Aamand J, Sorensen SJ (2004) Impact of DNA extraction method on bacterial community composition measured by denaturing gradient gel electrophoresis. Soil Biol Biochem 36:1607-1614

Eilers H, Pernthaler J, Glockner FO, Amann R (2000) Culturability and in situ abundance of pelagic bacteria from the North Sea. Appl Environ Microbiol 66:3044-3051

Felsenstein J (1985) PHYLIP (Phylogeny Inference Package). University of Washington, Seattle, WA

Friedrich AB, Merkert $H$, Fendert $T$, Hacker J, Proksch $P$, Hentschel U (1999) Microbial diversity in the marine sponge Aplysina cavernicola (formerly Verongia cavernicola) analyzed by fluorescence in situ hybridization (FISH). Mar Biol 134:461-470

Hagström Å, Pommier T, Rohwer F, Simu K, Stolte W, Svensson D, Zweifel UL (2002) Use of 16S ribosomal DNA for delineation of marine bacterioplankton species. Appl Environ Microbiol 68(7):3628-3633

Head IM, Saunders JR, Pickup RW (1998) Microbial evolution, diversity, and ecology: a decade of ribosomal RNA analysis of uncultivated microorganisms. Microb Ecol 35:1-21

Hentschel U, Schmid M, Wagner M, Fieseler L, Gernert C, Hacker J (2001) Isolation and phylogenetic analysis of bacteria with antimicrobial activities from the Mediterranean sponges Aplysina aerophoba and Aplysina cavernicola. FEMS Microbiol Ecol 35:305-312

Hentschel U, Hopke J, Horn M, Friedrich AB, Wagner M, Hacker J, Moore BS (2002) Molecular evidence for a uniform microbial community in sponges from different oceans. Appl Environ Microbiol 68:4431-4440

Katano T, Fukui M (2003) Molecular inference of dominant picocyanobacterial populations by denaturing gradient gel electrophoresis of PCR amplified 16S rRNA gene fragments. Phycol Res 51:71-76

Krsek M, Wellington EMH (1999) Comparison of different methods for the isolation and purification of total community DNA from soil. J Microbiol Method 39:1-16

Lane DJ, Pace B, Olsen GJ, Stahl DA, Sogin ML, Pace NR (1985) Rapid determination of $16 \mathrm{~S}$ ribosomal RNA sequences for phylogenetic analyses. Proc Natl Acad Sci 82:6955-6959

Martin SE, Flowers RS, Ordal ZJ (1976) Catalase: its effect on microbial enumeration. Appl Environ Microbiol 32: 731-734

Muller WEG, Grebenjuk VA, Thakur NL, Thakur AN, Batel R, Krasko A, Muller IM, Breter HJ (2004) Oxygen-controlled bacterial growth in the sponge Suberites domuncula: toward a molecular understanding of the symbiotic relationships between sponge and bacteria. Appl Environ Microbiol 70(4):2332-2341

Muyzer G, Smalla K (1998) Application of denaturing gradient gel electrophoresis (DGGE) and temperature gradient gel electrophoresis (TGGE) in microbial ecology. Antonie 
Leeuwenhoek 73:127-141

Muyzer G, Brinkhoff T, Nubel U, Santegoeds C, Schafer H, Wawer C (1997) Denaturing gradient gel electrophoresis (DGGE) in microbial ecology. Mol Microb Ecol Manual 3.4.4:1-27

Myers RM, Maniatis T, Lerman LS (1987) Detection and localization of single base changes by denaturing gradient gel electrophoresis. Method Enzymol 155:501-527

Olson JB, Lord CC, McCarthy PJ (2000) Improved recoverability of microbial colonies from marine sponge samples. Microb Ecol 40:139-147

Olson JB, Harmody DK, McCarthy PJ (2002) $\alpha$-Proteobacteria cultivated from marine sponges display branching rod morphology. FEMS Microbiol Lett 211:169-173

Padgett PJ, Cover WH, Krieg NR (1982) The microaerophilic Spirillum volutans: cultivation on complex liquid and solid media. Appl Environ Microbiol 43:469-477

Regoli F, Cerrano C, Chierici E, Chiantore MC, Bavestrello G (2004) Seasonal variability of prooxidant pressure and antioxidant adaptation to symbiosis in the Mediterranean demosponge Petrosia ficiformis. Mar Ecol Prog Ser 275: 129-137

Rohwer F, Breitbart M, Jara J, Azam F, Knowlton N (2001) Diversity of bacteria associated with the Caribbean coral Montastraea franksi. Coral Reefs 20:85-91

Roose-Amsaleg CL, Garnier-Sillam E, Harry M (2001) Extraction and purification of microbial DNA from soil and sediment samples. Appl Soil Ecol 18:47-60

Santavy D, Colwell RR (1990) Comparison of bacterial communities associated with the Caribbean sclerosponge Ceratoporella nicholsoni and ambient seawater. Mar Ecol Prog Ser 67:73-82

Santavy DL, Willenz P, Colwell RR (1990) Phenotypic study of bacteria associated with the Caribbean sclerosponge, Ceratoporella nicholsoni. Appl Environ Microbiol 56: $1750-1762$

Santegoeds CM, Nold SC, Ward DM (1996) Denaturing gradient gel electrophoresis used to monitor the enrichment culture of aerobic chemoorganotrophic bacteria from a hot spring cyanobacterial mat. Appl Environ Microbiol 62: 3922-3928

Sheffield VC, Cox DR, Lerman LS, Myers RM (1989) Attach-

Editorial responsibility: David Caron,

Los Angeles, California, USA ment of a 40-base-pair $\mathrm{G}+\mathrm{C}$-rich sequence (GC-clamp) to genomic DNA fragments by the polymerase chain reaction results in improved detection of single-base changes. Proc Natl Acad Sci USA 86:232-236

Suzuki MT, Giovannoni SJ (1996) Bias caused by template annealing in the amplification of mixtures of $16 \mathrm{~S}$ rRNA genes by PCR. Appl Environ Microbiol 62:625-630

Suzuki MT, Rappe MS, Haimberger ZW, Winfield H, Adair N, Strobel J, Giovannoni SJ (1997) Bacterial diversity among small-subunit rRNA gene clones and cellular isolates from the same seawater sample. Appl Environ Microbiol 63: 983-989

Swofford DL (2002) PAUP* — phylogenetic analysis using parsimony ( ${ }^{*}$ and other methods). Version 4.0b10. Sinauer Associates, Sunderland, MA

Taylor MW, Schupp PJ, Dahllof I, Kjelleberg S, Steinberg PD (2004) Host specificity in marine sponge-associated bacteria, and potential implications for marine microbial diversity. Environ Microbiol 6:121-130

Webster NS, Hill RT (2001) The culturable microbial community of the Great Barrier Reef sponge Rhopaloeides odorabile is dominated by an $\alpha$-Proteobacterium. Mar Biol 138: 843-851

Webster NS, Wilson KJ, Blackall LL, Hill RT (2001) Phylogenetic diversity of bacteria associated with the marine sponge Rhopaloeides odorabile. Appl Environ Microbiol 67:434-444

Webster NS, Negri AP, Munro MMHG, Battershill CN (2004) Diverse microbial communities inhabit Antarctic sponges. Environ Microbiol 6:288-300

Wilkinson CR (1978a) Microbial associations in sponges. I. Ecology, physiology and microbial populations of coral reef sponges. Mar Biol 49:161-167

Wilkinson CR (1978b) Microbial associations in sponges. II. Numerical analysis of sponge and water bacterial populations. Mar Biol 49:169-176

Wilkinson CR (1978c) Microbial associations in sponges. III. Ultrastructure of the in situ associations in coral reef sponges. Mar Biol 49:177-185

Wilkinson CR (1984) Immunological evidence for the Precambrian origin of bacterial symbioses in marine sponges. Proc R Soc Lond (Ser B) 220:509-517

Submitted: May 14, 2004; Accepted: December 28, 2004

Proofs received from author(s): April 4, 2005 